\title{
AKTIVITAS ANTIOKSIDAN EKSTRAK BUAH PARIJOTO PADA BERBAGAI PH PENGOLAHAN PANGAN
}

\author{
Umar Hafidz Asy’ari Hasbullah*, Rizki Bhakti Pertiwi, Isti Nurul Hidayah, Deby \\ Andrianty
}

Program Studi Teknologi Pangan, Universitas PGRI Semarang. Jl. Sidodadi Timur No. 24 Semarang, Jawa Tengah 50125; email: umarhafidzah@gmail.com

\begin{abstract}
Abstrak
Pengolahan pangan dapat dilakukan pada rentang $\mathrm{pH}$ dari asam hingga basa. Penelitian ini bertujuan untuk mempelajari pengaruh berbagai $\mathrm{pH}$ pengolahan pangan terhadap aktivitas antioksidan dan total fenol ekstrak buah parijoto. Penngujian dilakukan pada $\mathrm{pH} 2,4,7,8$, dan 10. Analisis aktivitas antioksidan menggunakan metode aktivitas penangkapan radikal DPPH. Sedangkan analisis fenol menggunakan metode folin ciocalteu. Hasil penelitian menunjukkan bahwa perbedaan $\mathrm{pH}$ berpengaruh signifikan terhadap aktivitas antioksidan dan total fenol ekstrak buah parijoto. Semakin meningkat pH menyebabkan kenaikan aktivitas antioksidan dan sejalan dengan terjadinya kenaikan total fenol. Aplikasi pengolahan produk dari buah parijoto pada $\mathrm{pH}$ yang lebih tinggi akan menghasilkan aktivitas antioksidan dan total fenol yang cenderung lebih tinggi.
\end{abstract}

Kata kunci: parijoto; pH pengolahan pangan; aktivitas antioksidan

\begin{abstract}
Food processing can be done in the $\mathrm{pH}$ range from acid to base. This research aims to study the effect of various $\mathrm{pH}$ of food processing on antioxidant activity and total phenol extract of Parijoto fruit. Testing was carried out at $\mathrm{pH} 2,4,7,8$, and 10. Analysis of antioxidant activity using the DPPH radical scavenging activity method. Whereas phenol analysis uses the Folin Ciocalteu method. The results showed that the $\mathrm{pH}$ difference significantly affected the antioxidant activity and the total phenol extract of Parijoto fruit. Increasing $\mathrm{pH}$ causes an increase in antioxidant activity and in line with an increase in total phenol. Application of processing products from Parijoto at higher $\mathrm{pH}$ will produce antioxidant activity and total phenols which tend to be higher.
\end{abstract}

Keywords: parijoto, $\mathrm{pH}$ food processing, antioxidant activity.

\section{PENDAHULUAN}

Penelitian terdahulu telah membuktikan bahwa buah parijoto mengandung senyawa antioksidan. Beberapa senyawa antioksidan yang dikandung buah parijoto antara lain antosianin, fenol, flavonoid, dan tannin (Wachidah, 2013; Ameliawati, 2018). Senyawa antioksidan memberikan kontribusi yang penting bagi kesehatan tubuh, terutama untuk mencegah dan mengatasi penyakit degenerative (Hasbullah et al., 2018).

Ekstrak parijoto telah terbukti mampu mengatasi terjadinya penyakit degenerative. Pemberian ekstrak parijoto mampu menurunkan glukosa darah pada hewan coba hiperglikemia (Febrilian dan Pujiastuti, 2017). Selain itu juga mampu menurunkan respon glukosa darah pada hewan coba diabetes (Rudianto dan Megawati, 2017). Ekstrak parijoto juga punya potensi sebagai ke kemoprevensi terhadap sel kanker payudara (Tussanti et al., 2014), menurunkan trigliserida pada hewan coba hyperlipidemia, mengatasi penumpukan lemak pada jaringan adiposa hewan coba (Sa'adah et al., 2002).

Senyawa antioksidan yang terkandung dalam buah parijoto memiliki aktivitas yang 
dipengaruhi beberapa factor. Penelitian terdahulu telah membuktikan bahwa perbedaan suhu mempengaruhi aktivitas antioksidan ekstrak parijoto (Pertiwi et al., 2019). Perubahan juga terjadi pada kandungan fenol dalam ekstrak parijoto. Selain suhu, $\mathrm{pH}$ ekstrak juga dimungkinkan berpengaruh terhadap aktivitas antioksidan.

Pegolahan buah parijoto menjadi berbagai produk pangan akan sangat berkaitan dengan kondisi $\mathrm{pH}$ produk yang dihasilkan. Hal ini tentunya akan mempengaruhi antivitas antioksidan dari produk yang dihasilkan. Penelitian ini akan mempelajari pengaruh $\mathrm{pH}$ terhadap aktivitas antioksidan ekstrak buah parijoto.

\section{BAHAN DAN METODE}

\section{Bahan}

Buah parijoto berasal dari Lereng Gunung Muria, Kudus, Jawa Tengah. Buah dipilih yang berwarna merah tua keunguan dan tidak ada kerusakan.

\section{Ekstraksi dan Pengujian Ekstrak}

Ekstrak parijoto dibuat dengan maserasi 50 gram buah parijoto halus dengan etanol $96 \%$ dengan rasio parijoto:etanol ( $1: 5 \mathrm{~b} / \mathrm{v})$ selama 24 jam pada suhu kamar. Ekstrak dipisahkan dari ampas dengan penyaringan dalam kertas saring. Maseriasi dilakukan kembali terhadap ampas dengan kondisi yang sama. Ekstrak maserasi pertama dan kedua digabungkan dan dievaporasi dengan rotary vacuum evaporator $\left(45^{\circ} \mathrm{C}\right)$. ekstrak pekat disimpan dalam botol kaca gelap pada suhu dingin sampai dianalisis.

Pengujian ekstrak parijoto dilakukan dengan mengencerkan dalam buffer $\mathrm{pH}$ dengan rasio 1:3 (v/v) dalam tabung reaksi. Larutan buffer $\mathrm{pH}$ yang diujikan terdiri dari $\mathrm{pH}$ 2,4,7,8, dan 10. Selanjutnya divortex 1 menit dan diinkubasi 5 menit pada suhu kamar.

\section{Analisis Aktivitas Antioksidan}

Pengujian aktivitas antioksidan mengacu pada Gulcim et al., (2010) yang dimodifikasi. Sampel $(4 \mathrm{ml})$ dalam tabung reaksi direaksikan dengan 0,5 ml larutan DPPH (1,1-Diphenil-2- pikrilhidrazil) 0,7mM. Homogenisasi dengan vorteks selama 1 menit. Inkubasi dilakukan selama 30 menit dalam ruang gelap pada suhu kamar. selanjutnya ditera absorbansi pada panjang gelombang $517 \quad \mathrm{~nm}$ dengan spektrofotometer UV-Vis (Spectroquant Proove 300, Merck). Kontrol merupakan larutan DPPH tanpa direaksikan dengan sampel. Aktivitas antioksidan dinyatakan sebahai persentase penghambatan radikal DPPH.

Aktivitas antioksidan (\%) $=($ Ak-As $) / A k X 100$

Dimana Ak merupakan absorbandi kontrol dan As merupakan absorbansi sampel.

\section{Analisis Total Fenol}

Pengujian total fenol mengacu pada Han et al. (2019) yang dimodifikasi. Sampel (1 ml) direaksikan dengan $5 \mathrm{ml}$ Larutan Na2CO3. Selanjutnya dihomogenkan dengan vorteks dan diinkubasi pada suhu kamar selama 10 menit. Kemudian direaksikan dengan 0,5 ml FolinCiocalteu. Homogenisasi dengan vorteks dilakukan selama 1 menit dan dilanjutkan inkubasi selama 30 menit pada suhu kamar. absorbansi sampel ditera menggunakan spektrofotometer UV-Vis (Spectroquant Proove 300 , Merck) pada panjang gelombang $765 \mathrm{~nm}$. Kurva standar venol dibuat dengan senyawa phenol standart (Merck). Total fenol dinyatakan sebagai $\mu g$ phenol equivalent/ $\mathrm{ml}$ sampel.

\section{Analisis Data}

Data hasil penelitian dianalisis dengan OneWay ANOVA menggunakan bantuan software SPSS versi 21. Perbedaan signifikan ditunjukkan dengan $\mathrm{P}<0,05$.

\section{HASIL DAN PEMBAHASAN}

\section{Aktivitas Antioksidan}

Kenaikan aktivitas antioksidan terjadi seiring dengan kenaikan $\mathrm{pH}$ (Gambar 1). Nilai aktivitas antioksidan pada $\mathrm{pH}$ asam (2 dan 4) cenderung lebih rendah dibanding $\mathrm{pH}$ lainnya dan berbeda signifikan. Aktivitas antioksidan $\mathrm{pH} 2$ paling rendah dari seluruh perlakuan. Kenaikan $\mathrm{pH}$ mencapai optimum hingga $\mathrm{pH} 7$ dimana semakin naik $\mathrm{pH}$ tidak menyebabkan 
perubahan aktivitas antioksidan yang berbeda signifikan.

Hasil penelitian ini berlawanan dengan Bayliak et al. (2016) yang menyatakan bahwa pada $\mathrm{pH}$ alkali terjadi penurunan aktivitas antioksidan ekstrak tanaman. Akan tetapi hal yang berbeda dilaporkan Amorati et al. (2006) bahwa peningkatan $\mathrm{pH}$ pada senyawa fenol akan menaikkan aktivitas antioksidannya. Sehingga sesuai dengan hasil penelitian ini. Pada media asam dengan $\mathrm{pH}$ rendah menyebabkan asam fenolik menunjukkan perilaku sebagai inhibitor prooksidan yang lemah. Pada $\mathrm{pH}$ basa menunjukkan fase lag yang 2-3 kali lebih lama dari trolox.

Kecenderungan pengaruh kenaikan $\mathrm{pH}$ terhadap aktivitas antioksidan ekstrak parijoto terlihat semakin meningkat $\mathrm{pH}$ menyebabkan semakin naiknya aktivitas antioksidan (Gambar 2). Hal ini menunjukkan bahwa penggunaan $\mathrm{pH}$ yang lebih tinggi dalam pengolahan pangan akan mampu mempertahankan aktivitas antioksidan dari produk.

\section{Total Fenol}

Semakin meningkat $\mathrm{pH}$ menyebabkan kenaikan kandungan senyawa fenol dalam ekstrak parijoto (Gambar 3). Total fenol pada $\mathrm{pH}$ asam berbeda signifikan dengan $\mathrm{pH}$ basa. Menurut Amorati et al. (2006) senyawa fenol akan lebih stabil pada $\mathrm{pH}$ basa. Pada media larutan kemampuan fenol berperan sebagai antioksidan berkaitan dengan transfer atom hidrogen dari fenol ke peroksil radikal. Selain itu $\mathrm{pH}$ larutan berpengaruh pada reaktivitas anion fenolat terhadap radikal peroksil. Pada ekstrak polifenol daun ubi jalar menunjukkan hal yang serupa dimana kenaikan $\mathrm{pH}$ dari 3 hingga 7 menyebabkan kenaikan nilai total fenol (Sun et al., 2017).

Kecenderungan pengaruh kenaikan $\mathrm{pH}$ terhadap total fenol dapat dilihat bahwa semakin meningkat $\mathrm{pH}$ akan menyebabkan total fenol dalam ekstrak parijoto akan memiliki kecenderungan semakin memingkat (Gambar 4). Hal ini menunjukkan bahwa penggunaan $\mathrm{pH}$ tinggi dalam pengolahan produk olahan buah parijoto akan mampu mempertahankan kandungan fenol dalam produk.

Beberapa $\mathrm{pH}$ yang digunakan dalam penelitian ini mewakili dari berbagai pengolahan dan produk pangan. $\mathrm{pH}$ rendah atau $\mathrm{pH}$ asam mewakili pengolahan buah parijoto dalam sari buah yang biasanya ditambah asam sitrat, dan ketika dijadikan campuran produk yoghurt. $\mathrm{pH}$ netral mewakili $\mathrm{pH}$ pengolahan parijoto pada campuran susu yang biasanya berada disekitar $\mathrm{pH}$ netral. Sedangkan $\mathrm{pH}$ tinggi atau $\mathrm{pH}$ basa mewakili pengolahan buah parijoto saat direndam dalam air kapur atau kalsium karbonat dan aplikasi dalam minuman berkarbonasi.

Berdasarkan hasil penelitian ini dapat dilihat hasil yang singkron antara perubahan total fenol dan aktivitas antioksidan dengan perubahan $\mathrm{pH}$. Hal ini menunjukkan kontribusi fenol terhadap aktivitas antioksidan ekstrak parijoto pada perlakuan berbagai $\mathrm{pH}$ pengolahan pangan. Peningkatan total fenol yang terjadi akibat meningkatnya $\mathrm{pH}$ berdampak terhadap peningkatan aktivitas antioksidan ekatrak buah parijoto, dan sebaliknya.

\section{SIMPULAN}

Pengaruh $\mathrm{pH}$ terhadap aktivitas antioksidan dan total senyawa fenol menunjukkan semakin meningkat $\mathrm{pH}$ akan meningkatkan aktivitas antioksidan dan total senyawa fenol dalam ekstrak buah parijoto.

\section{DAFTAR PUSTAKA}

Ameliawati, R. 2018. Pengaruh umur panen dan jenis pelarut terhadap kandungan total fenolik, antosianin dan aktivitas antioksi dan ekstrak buah parijoto (Medinilla speciosa Blume). Skripsi. Fakultas Teknologi Pertanian, Universitas Gadjah Mada, Yogyakarta 
Amorati, R., G. F. Pedulli, L. Cabrini, L. Zambonin, and L. Landi. 2006. Journal of Agricultural and Food Chemistry 54(8): 2932-2937. DOI: $10.1021 / \mathrm{jf0} 03159+$.

Bayliak, M. M., N. I. Burdyliuk, V. I. Lushchak. 2016. Effects of $\mathrm{pH}$ on antioxidant and prooxidant properties of common medicinal herbs. Open Life Sci. 11: 298-307.

Febrilian, O. V., dan E. Pujiastuti. 2017. Uji Efektivitas Ekstrak Buah Parijoto (medinilla speciosa Blume) terhadap Kadar Glukosa Darah pada Tikus Putih Wistar yang dibebani Sukrosa. Prosiding HEFA, p. 341-346.

Gulcin, I., Z. Huyut, M. Elmastas, HY. AboulEnein. 2010. Radical scavenging and antioxidant activity of tannic acid. Arabian Journal of Chemistry 3(1):4353.

DOI:10.1016/j.arabjc.2009.12.008.

Han, M., G. Li, X. Liu, A. Li, P. Mao, P. Liu, H. Li. 2019. Phenolic profile, antioxidant activity and anti-poliferative activity of Crabapple fruits. Horticultural Plant Journal.

DOI:

10.1016/j.hpj.2019.01.003.

Hasbullah, UHA., RB. Pertiwi, N. Khikmah, D. Novita. 2018. Parijoto, kandungan, manfaat dan pengolahannya. PT. Nasya Expanding Management. Pekalongan. ISBN: 978-602-5737-26-

8.

Pertiwi, R.B., I. N. Hidayah, D. Andrianty, U. H. A. Hasbullah. 2019. Aktivitas Antioksidan Ekstrak Buah Parijoto pada Berbagai Suhu Pengolahan Pangan. Jurnal Ilmu Pangan dan Hasil Pertanian 3(1):22-30.
Rudianto dan A. Megawati. 2017. Pengaruh Pemberian Ekstrak Buah Parijoto (Medinilla speciosa Blume) Terhadap PenurunanKadar Glukosa Darah Pada Tikus Putih. Prosiding HEFA 1st. LPPMSTIKES Cendekia Utama Kudus. P 369-374. ISSN 2581 2270.

Sa'adah, N.N., A.P.D. Nurhayati, and K.I. Purwani. 2002. Antihyperlipidemic and Anti-obesity Effectsof the Methanolic Extract of Parijoto (Medinilla speciosa). AIP Conf. Proc. p:020046-1-020046-8. https://doi.org/10.1063/1.5050142.

Sun, H N., T.H. Mu, and L.S. Xi. 2017. Effect of $\mathrm{pH}$, heat, and light treatments on the antioxidant activity of sweet potato leaf polyphenols. International Journal of Food Properties 20(2):318332.

DOI: 10.1080/10942912.2016.1160410.

Tussanti, I.,A. Johan, Kisdjamiatun. 2014. Sitotoksisitas in vitro ekstrak etanolik buah parijoto (Medinilla speciosa, reinw. ex bl.) terhadap sel kanker payudara T47D. Jurnal Gizi Indonesia2(2): 53-58.

Wachidah, LN. 2013. Uji aktivitas antioksidan serta penentuan kandungan fenolat dan flavonoid total dasr buah parijoto (Medinilla speciose Blume). Skripsi Program Studi Farmasi Fakultas Kedokteran dan IImu Kesehatan UIN Syarif Hidayatullah. 
Hasbullah, et al. 2020

Lampiran

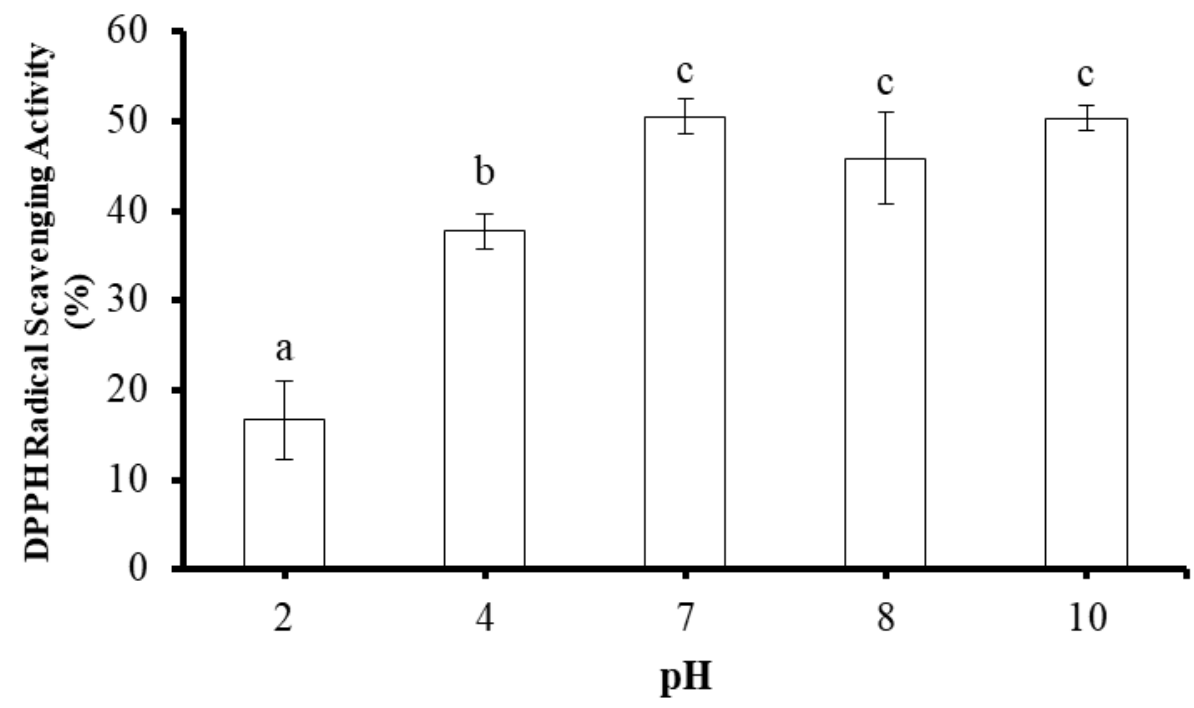

Gambar 1. DPPH Radical Scevenging Activity ekstrak buah parijoto pada perlakuan $\mathrm{pH}$ pengolahan. Notasi yang berbeda menunjukkan perbedaan signifikan $(P<0.05)$. Data disajikan dengan garis standard deviasi.

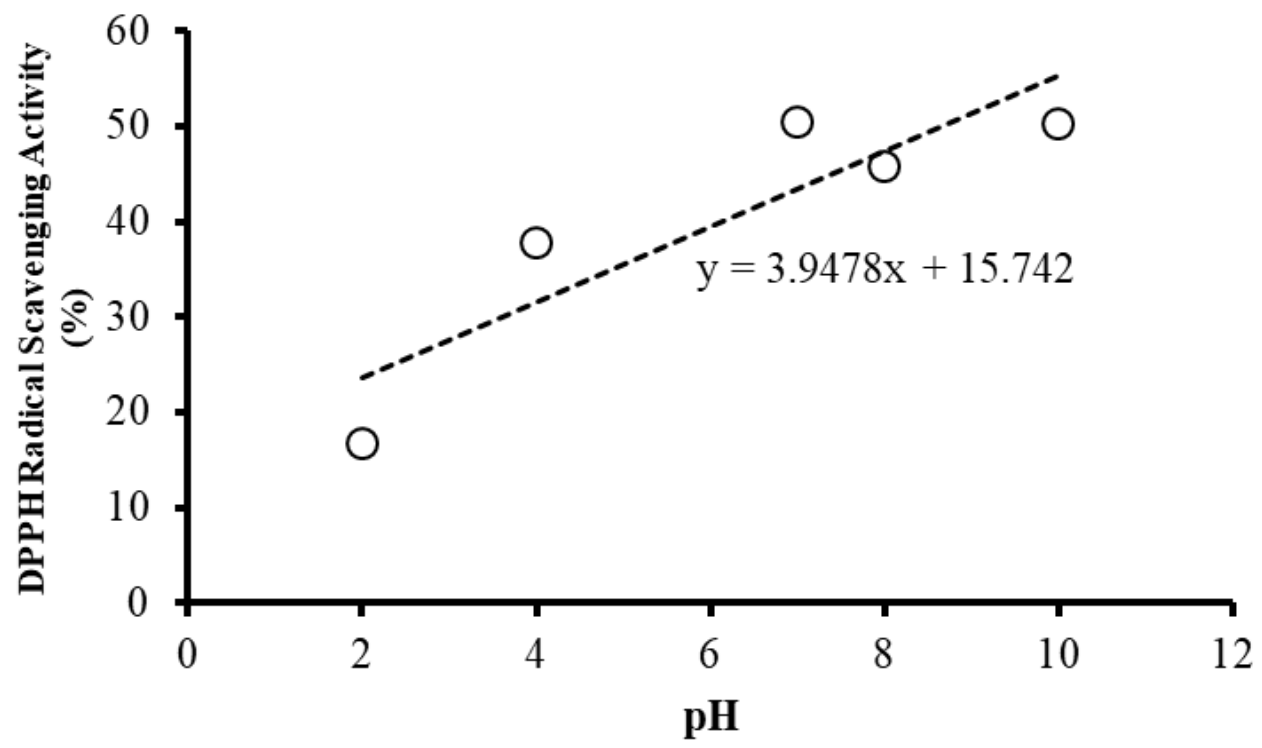

Gambar 2. Pola regresi linear DPPH Radical Scevenging Activity ekstrak buah parijoto pada perlakuan $\mathrm{pH}$ pengolahan. 
Agrisaintifika

Jurnal Ilmu-Ilmu Pertanian

Vol. 4, No. 2, 2020

Hasbullah, et al. 2020

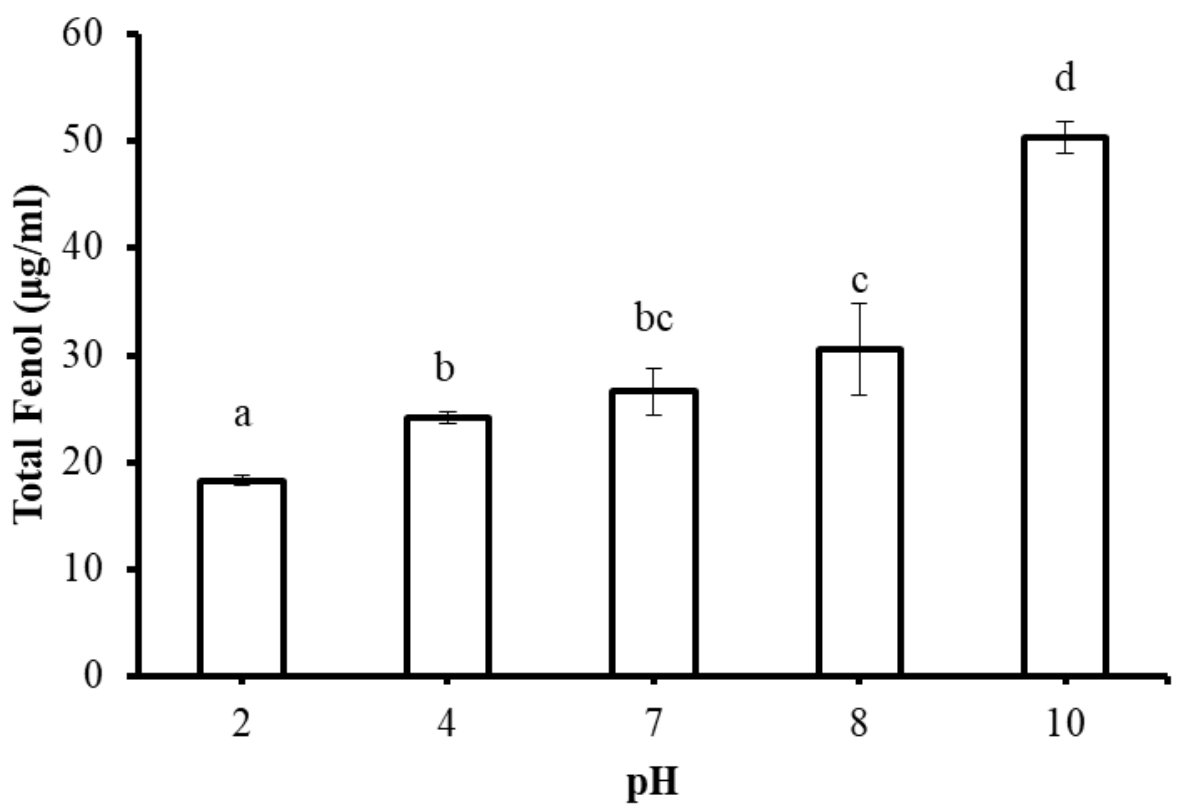

Gambar 3. Total fenol ekstrak buah parijoto pada perlakuan $\mathrm{pH}$ pengolahan. Notasi yang berbeda menunjukkan perbedaan signifikan $(P<0.05)$. Data disajikan dengan garis standard deviasi.

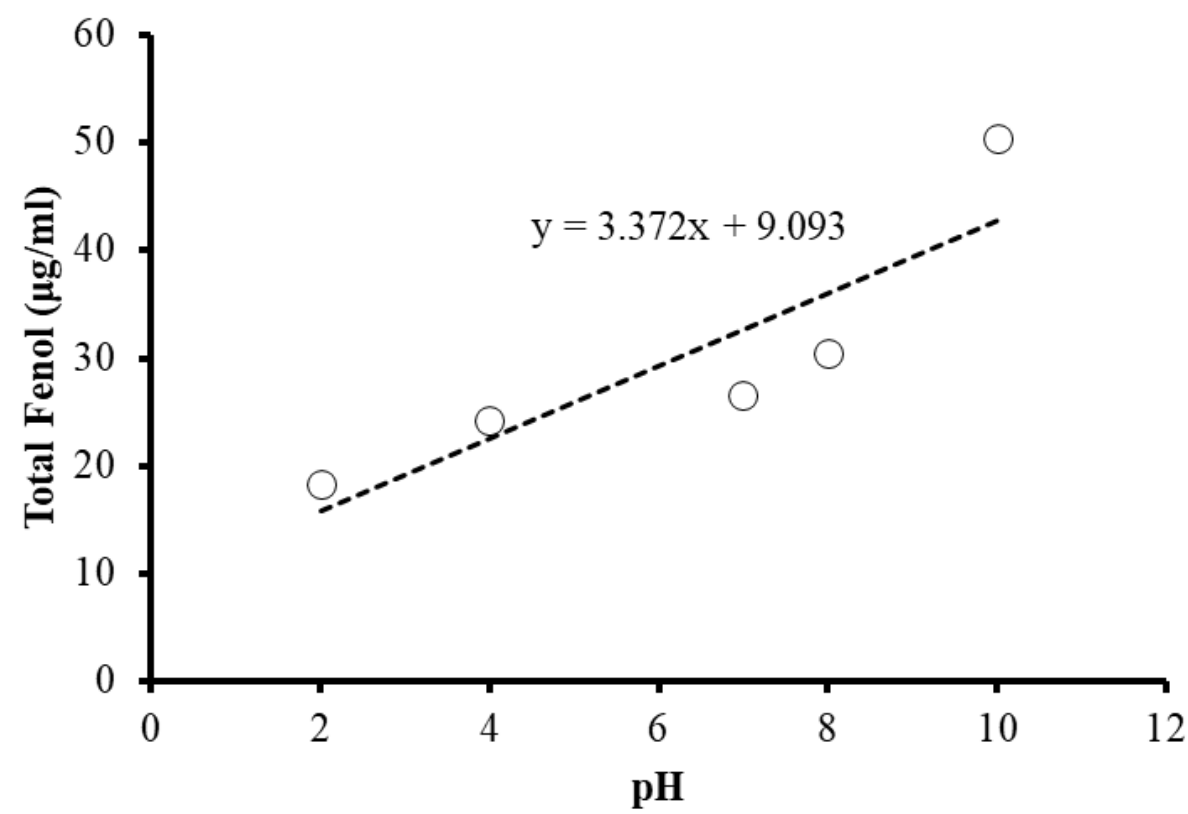

Gambar 4. Pola regresi linear total fenol ekstrak buah parijoto pada perlakuan $\mathrm{pH}$ pengolahan. 